\title{
РАЗВИТИЕ УЧЕТА В РОССИИ В УСЛОВИЯХ ПЕРЕХОДА К ЦИФРОВОЙ ЭКОНОМИКЕ И ИСКУССТВЕННОГО ИНТЕЛЛЕКТА
}

\author{
(c) 2021 Косолапова М.В.
}

доктор экономических наук, профессор Департамента аудита и корпоративной отчетности Финансовый университет при Правительстве Российской Федерации, Россия, Москва

E-mail:MVKosolapova@fa.ru

(c) 2021 Манвелова И.А.

доцент Департамента английского языка и профессиональной коммуникации Финансовый университет при Правительстве Российской Федерации, Россия, Москва

E-mail: IAManvelova@fa.ru

Среди большого количества направлений развития мировой экономики на сегодняшний день особое внимание уделяется постепенному переходу к цифровым технологиям, в которых первостепенную роль играет такой ресурс как информация. Логичным следствием этого стало формирование информационного общества, а затем и появление понятия цифровой экономики, в которой данные в цифровой форме являются ключевым фактором производства во всех сферах деятельности общества, включая такую сферу, как бухгалтерский учет.

Ключевые слова: учет, анализ, аудит, цифровая экономика, искусственный интеллект

Сам термин «цифровая экономика»- понятие относительно новое, впервые упомянутое в 1995 году Николасом Негропонте - американским ученым из Массачусетского университета. Употреблен данный термин был для разъяснения преимуществ нового уклада экономики перед старым в связи с форсированным развитием широкого спектра информационных технологий. Однозначной трактовки термина цифровой экономики не существует по сей день, однако в утвержденной и опубликованной Российской Федерацией Стратегии развития информационного общества РФ на 2017-2030 годы дается достаточно полное и точное определение данного понятия: «Цифровая экономика - это хозяйственная деятельность, в которой ключевым фактором производства являются данные в цифровом виде, обработка больших объемов и использование результатов анализа которых по сравнению с традиционными формами хозяйствования позволяют существенно повысить эффективность различных видов производства, технологий, оборудования, хранения, продажи, доставки товаров и услуг». В современных условиях переход к цифровой экономике формирует качественно новую парадигму развития методологии ведения бухгалтерского учета.

В условиях постепенного перехода от аналогового ведения бизнеса к цифровому, происходит формирование среды цифровой экономики, которая несомненно вносит существенные из- менения в требования к системе сбора, обработки и хранения информации. В связи с этим, на новое направление экономики должным образом необходимо адаптироваться методологии бухгалтерского учета.

Одной из важнейших частей всей системы бухгалтерского учета является информационная составляющая двух основополагающих подсистем - управленческого и финансового учета. На данный момент в организации заметна тенденция, побуждающая к смене концентрации бухгалтерского учета с контрольной функции на информативную, основывающуюся на цифровой трансформации организации. Разрабатываются новые показатели, способы сбора и обработки полученной финансовой информации, а также важным аспектом является обеспечение ее интегрированности с информацией о других частях бизнеса и внешней среды. Развитие теории и совершенствование практики ведения бухгалтерского учета неразрывно связано с трансформацией экономики и расширением информационного потенциала существующего экономического пространства.

В последнее время наиболее важным стал вопрос об использовании информационных технологий в практике ведения бухгалтерского учета. Цифровая трансформация постепенно привела к тому, что сейчас уже трудно найти организацию, которая не использует различные специализированные программы (напри- 
мер, «1С-Бухгалтерия», «Финансовый аналитик», «Контур», «Парус»), которые позволяют классифицировать и группировать факты хозяйственной жизни, передавать полученную информацию, а также осуществлять оперативный анализ, существенно упрощая и улучшая при этом качество ведения бухгалтерского учета. В связи с повсеместным использованием этих систем подавляющее большинство операций бухгалтерского учета, приняли цифровую форму, что послужило появлению такого понятия как «цифровой бухгалтерский учет», подразумевающего под собой оцифрованный процесс бухгалтерского учета, включающий в себя процессы обработки, формирования и передачи финансовой информации при помощи различных цифровых методов и инструментов. Данные инструменты помогают сделать учет более гибким в осуществлении повседневных процессов. Они касаются таких объектов, как:

- первичные документы (формирование первичного документооборота в структурированном цифровом виде)

- бухгалтерские проводки (автоматизированное формирование бухгалтерских проводок на основании внесенного цифрового первичного документа в структурированном виде)

- аналитика (проведение анализа основных показателей финансово-хозяйственной деятельности)

- отчетность (автоматизированное формирование и направление бухгалтерской и регламентированной отчетности, а также ее подписание с помощью электронной подписи).

Таким образом, цифровой учет позволяет формировать, передавать, интерпретировать и анализировать данные бухгалтерского учета в электронном виде.

В настоящее время укрепляется понимание того, что аналитика, анализ данных обеспечивают правильность принимаемых решений в условиях ограниченных ресурсов и рынков сбыта, позволяя компании устойчиво существовать на высококонкурентном рынке. Используя специализированные программные продукты для обработки финансовой информации в цифровом виде, поступающей из бухгалтерского учета, можно решать возникающие задачи, формировать как оперативные, так и стратегические планы, различные прогнозы, а также продумывать и изменять стратегию компании, отталкиваясь от изменения ключевых значений тех или иных факторов.
В условиях развития цифровой экономики значительные изменения затрагивают и объекты учета. Согласно программе «Цифровой экономики Российской Федерации», данные становятся новым активом, причем, главным образом за счет их альтернативной ценности, то есть по мере применения данных в новых целях и их использования для реализации новых идей. Таким образом, цифровые активы можно рассматривать как новый вид объектов учета. К ним можно отнести интеллектуальный человеческий капитал, клиентскую базу, результаты НИОКР, инновационные продукты и т.п. Вследствие этого, происходит всестороннее изучение возможностей их корректной оценки и учета. Также происходит включение в систему бухгалтерского учёта данных нефинансового характера. Разрабатываются и применяются новые информационные технологии, такие как «облачные» технологии, управление «большими данными» открытые технологические платформы, электронные справочно-информационные системы, создание единого международного формата и содержания финансовой отчетности в электронном виде XBRL. Развитие информационных технологий позволяет в ближайшей перспективе ожидать расширения применения элементов искусственного интеллекта в работе с информацией для осуществления процессов систематизации, структурирования и маршрутизации документов. Очевидно, это даст толчок к созданию национальной системы бухгалтерского учёта, где будет происходить интеграция данных, определяющих состояние внутренних бизнес-процессов предприятия и внешней среды.

Трансформация экономики заставляет по-новому взглянуть на механизм работы предприятий. В условиях цифровизации экономической деятельности бухгалтерский учет позиционируется как элемент системы получения, обработки и передачи данных о состоянии организации на текущий момент времени. Параллельно с этим укрепляется понимание того, что аналитика, анализ данных обеспечивают правильность принимаемых решений в условиях ограниченных ресурсов и рынков сбыта, дают конкурентное преимущество. Информация, и в частности учетная информация, играет ключевую роль в управлении организацией, а бухгалтерский учет - является определяющей частью информационной системы предприятия. 


\section{Библиографический список}

1. Об утверждении программы «Цифровая экономика Российской Федерации»: распоряжение Правительства РФ от 28.07.2017 № 1632-р // Собрание законодательства Российской Федерации. - 2017.

2. Бобылева М.П. Некоторые вопросы цифровой трансформации традиционных процессов и процедур // Делопроизводство. 2019. N 3

3. Будович Ю.И. Цифровизация корпоративного учета // Человеческий капитал в формате цифровой экономики. - 2018.

4. Серова Г. А. Роль цифровизации делопроизводства в цифровом офисе компании // Делопроизводство. 2019. N 3

5. Ермилова Ю.А. Аспекты учетно-аналитического обеспечения инновационной деятельности на предприятия // Региональная инновационная экономика: сущность, элементы, проблемы формирования, новые вызовы. Ульяновск, - 2016.

6. Сафонова М.Ф. Развитие методики бухгалтерской экспертизы в условиях цифровой экономики // Международный бухгалтерский учет. 2019. N 2

7. Карпова Т.П. Направления развития бухгалтерского учета в цифровой экономике // Известия СанктПетербургского Государственного Экономического Университета. - 2018. N 3.

8. https://bizeducate.com/11/2018/tsifrovye-tehnologii-v-buhgalterskoj-i-auditorskoj-deyatelnosti/

9. Петров А.М., Мельникова Л. А. Теоретические аспекты учета калькулирования себестоимости продукции / Экономические науки. 2013. № 102. С. 145-148.

10. Петров А.М., Мельникова Л. А. Формирование отчетности в соответствии с требованиями МСФО как объективная необходимость на современном этапе развития экономики РФ / Проблемы современной экономики. 2017. № 2 (62). С. 105-107.

11. Петров А. М. Общественное питание 6 в 1: учетная политика, документооборот, калькулирование себестоимости, бухгалтерский учет, налоги, отчетность / А. М.Петров. Москва, 2011. Сер. Полное руководство бухгалтера 